\title{
Arsenic trioxide nanoparticles inhibit acute promyelocytic leukemia cell proliferation and induce apoptosis via PTEN/AKT signalling pathway.
}

\author{
Yalin Wang', Yi Dong², Yingmin Liu ${ }^{1}$, Ziling Liu ${ }^{\text {* }}$ \\ ${ }^{1}$ Cancer Center, the First Hospital of Jilin University, Jilin, P.R. China \\ ${ }^{2}$ Department of Oncology, the Affiliated Hospital of Cheng De Medical College, Hebei, P.R. China
}

\begin{abstract}
Background: Arsenic Trioxide $\left(\mathrm{As}_{2} \mathrm{O}_{3}\right)$ is a FDA-approved agent for the treatment of Acute Promyelocytic Leukemia (APL). But the high-toxicity is a bottleneck of the effect of $\mathrm{As}_{2} \mathrm{O}_{3}$.

Methods: In our previous work, we made a novel nanoparticle formulation of $\mathrm{As}_{2} \mathrm{O}_{3}$. The aim of the present study was to preliminary study the possible mechanisms of the antitumor effect of $\mathrm{As}_{2} \mathrm{O}_{3}$ nanoparticles on NB4 cells. We examined the proliferation and apoptosis of NB4 cells incubated with the $\mathrm{As}_{2} \mathrm{O}_{3}$ or $\mathrm{As}_{2} \mathrm{O}_{3}$ nanoparticles. Protein levels of p-PTEN, p-AKT, Bax, caspase-3, caspase-9 and AIF of $\mathrm{NB} 4$ cells after using $\mathrm{As}_{2} \mathrm{O}_{3}$ nanoparticles and traditional $\mathrm{As}_{2} \mathrm{O}_{3}$ were determined by Western blotting analysis.

Results: In vitro cytotoxicity test showed that the inhibition rate and apoptosis level of NB4 cells treated with $\mathrm{As}_{2} \mathrm{O}_{3}$ nanoparticles was much higher than that of traditional $\mathrm{As}_{2} \mathrm{O}_{3}$. Moreover, $\mathrm{As}_{2} \mathrm{O}_{3}$ nanoparticles resulted in a more significant increase in p-PTEN expression and a greater reduction in pAkt expression compared with traditional $\mathrm{As}_{2} \mathrm{O}_{3}$.

Conclusions: Our findings indicated the obvious anticancer effect of $\mathrm{As}_{2} \mathrm{O}_{3}$ nanoparticles and demonstrate the possible mechanism of its therapeutic potential. The results provide a foundation for the future clinical studies of $\mathrm{As}_{2} \mathrm{O}_{3}$ nanoparticles in APL patients.
\end{abstract}

Keywords: Arsenic trioxide, Acute promyelocytic leukemia, Nanoparticles, PTEN, Akt.

Accepted on January 30, 2018

\section{Introduction}

Acute Promyelocytic Leukemia (APL) is the M3 subtype of acute myelogenous leukemia and cytogenetically is characterized by a translocation of chromosomes 15 and 17 , which results in the fusion between Retinoic Acid Receptor $\alpha$ $(R A R \alpha)$ and the Promyelocytic Leukemia $(P M L)$ gene. APL is always accompanied with severe bleeding tendency and disseminated intravascular coagulation. The first-line treatment of APL was chemotherapy. More than $80 \%$ of patients treated with all-trans retinoic acid along with chemotherapy can achieve a prolonged remission. Relapsed patients are often treated with arsenic trioxide successfully [1].

Arsenic Trioxide $\left(\mathrm{As}_{2} \mathrm{O}_{3}\right)$ is the primary component of arsenic (pishuang), a kind of traditional Chinese medicine. In the early 1970's, some Chinese physicians from Harbin Medical University recognized arsenic as an effective ingredient for leukemia treatment. In 1996 and 1997, notable effect was reported for the use of $\mathrm{As}_{2} \mathrm{O}_{3}$ in APL [2]. The Food and Drug Administration (FDA) approved $\mathrm{As}_{2} \mathrm{O}_{3}$ as frontline treatment for APL in 2000 [3]. Apart from APL, it was used in several kinds of diseases, such as Chronic Lymphocytic Leukemia (CLL), liver cancer, syphilis, psoriasis, rheumatism [4-7]. However, the toxicity of arsenic was recognised by people gradually. The side effect of long-term chronic exposure to arsenic include hyperpigmentation of the skin, hyperkeratosis of the palms and feet, cancers of lung, bladder, prostate, kidney, liver as well as neuropathy, leucopenia, encephalopathy, peripheral vascular diseases and diabetes. Consequently, it faded out from clinical applications owing to its toxicity and carcinogenic properties [5].

Nanoparticles are becoming an emerging treatment modality for cancer. The advantages of nanoparticles are delivering anticancer drugs to the tumor, the ability to enhance permeability, bioavailability and efficacy as well as reduction or reversion of multidrug resistance. Owing to the unique features of tumor vasculature, the "Enhanced Permeability and Retention (EPR) effect" allows nanoparticles to extravasate into extravascular spaces and increase the drug concentration inside tumor tissues more than free drugs [8]. Nowadays, most nanoparticles can selectively target on cancer cells, reducing the undesirable side effects of conventional chemotherapy, and therefore improving the efficacy of patients $[9,10]$.

The $\mathrm{As}_{2} \mathrm{O}_{3}$ nanoparticles were prepared with the so-gel method. In this study, the in vitro effect of $\mathrm{As}_{2} \mathrm{O}_{3}$ nanoparticles on NB4 cells was assessed by evaluating MTT analysis, mitochondrial membrane potential and flow cytometric 
analysis. Furthermore, we explore the possible mechanism of by detecting the protein levels of p-PTEN, p-AKT, Bax, caspase-3, caspase-9 and AIF.

\section{Methods}

\section{Cell culture}

NB4 cells were a kind gift from Dr. Jifan $\mathrm{Hu}$ at Stanford University Medical School (Palo Alto, CA, USA) for research in the laboratory of the First Affiliated Hospital of Jilin University (Changchun, China). NB4 cells were cultured in Iscove's Modified Dulbecco's Medium (Gibco-BRL, Grand Island, NY, USA) containing heat inactivated 10\% Fetal Bovine Serum (FBS) (Hanzhou Sijiqing Biological Engineering Materials Co., Ltd. Hanzhou, China) along with $100 \mathrm{U} / \mathrm{ml}$ of penicillin and $0.1 \mathrm{mg} / \mathrm{ml}$ of streptomycin in an atmosphere of $5 \% \mathrm{CO}_{2}$ and $100 \%$ humidity.

\section{Preparation of $\mathrm{As}_{2} \mathrm{O}_{3}$ nanoparticles}

The $\mathrm{As}_{2} \mathrm{O}_{3}$ nanoparticles were synthesized with the sol-gel method as we previously described [11]. The preparation method was as follows: $\mathrm{As}_{2} \mathrm{O}_{3}$ powder and hydrochloric acid were mixed and stirred for $1030 \mathrm{~min}$. Ethanol was then added, the solution was stirred at $5060^{\circ} \mathrm{C}$ for $2030 \mathrm{~min}$ and sonicated for $5 \mathrm{~min}$. Finally, distilled water was added, and the mixture was sonicated for another $1020 \mathrm{~min}$.

\section{MTT analysis}

The inhibitory effect of $\mathrm{As}_{2} \mathrm{O}_{3}$ (Institute for Drug Control of the Ministry of Health of China) and $\mathrm{As}_{2} \mathrm{O}_{3}$ nanoparticles was estimated by MTT assay. There were 3 groups, which were control, $\mathrm{As}_{2} \mathrm{O}_{3}$ and $\mathrm{As}_{2} \mathrm{O}_{3}$ nanoparticles. NB4 cells were seeded on 96 well plates in quadruplicate at a density of $2 \times$ $10^{5} /$ well in $100 \mu \mathrm{l}$. $\mathrm{As}_{2} \mathrm{O}_{3}$ and $\mathrm{As}_{2} \mathrm{O}_{3}$ nanoparticles (4 different final concentrations: $0.5,1,2,4 \mu \mathrm{mol} / \mathrm{L}$ ) were added at the right time according to the group setting. After 24, 48 and $72 \mathrm{~h}$ of treatment, the cells were incubated for 3-4 h with MTT (Changchun Biotech Co., Ltd. Changchun, China) and lysed with acidified isopropanol. Absorbance was measured at 570 nm. The inhibition rate was calculated using the following formula: Inhibition rate $=(($ absorbance value of control groupabsorbance value of test group)/absorbance value of control group) $\times 100 \%$. All experiments were repeated three times.

\section{Hoechst 33342/PI staining}

Cellular nuclear was stained with Hoechst 33342 (Hoechst Pharmaceuticals) and Propidium Iodide (PI) to observe the cellular apoptosis or necrosis situation by fluorescence microscopy. Briefly, $1 \times 10^{6} \mathrm{NB} 4$ cells were incubated with 3 $\mu \mathrm{mol} / \mathrm{L} \mathrm{As}_{2} \mathrm{O}_{3}$ and $\mathrm{As}_{2} \mathrm{O}_{3}$ nanoparticles for $24 \mathrm{~h}$. Cells were washed with PBS, suspended with new fresh medium, double stained with Hoechst 33342/PI and visualised by fluorescence microscopy.

\section{Flow cytometric analysis}

NB4 cells were treated with $1.5 \mu \mathrm{mol} / \mathrm{L}$ and $3.0 \mu \mathrm{mol} / \mathrm{L} \mathrm{As}_{2} \mathrm{O}_{3}$, $\mathrm{As}_{2} \mathrm{O}_{3}$ nanoparticles against untreated control for $24 \mathrm{~h}$ at $37^{\circ} \mathrm{C}$ with $5 \% \mathrm{CO}_{2}$. After treatment, $1 \times 10^{5} \mathrm{NB} 4$ cells were stained with Annexin V/Propidium Iodide Apoptosis Detection Assay kit (Beyotime Institute of Biotechnology Co., Shanghai, China). The apoptosis of NB4 cells in 3 groups were examined by flow cytometry (FCM; FACSCalibur ${ }^{\mathrm{TM}}$, BD Biosciences, San Jose, CA, USA).

\section{Mitochondrial membrane potential}

NB4 cells were incubated with 1.5 and $3 \mu \mathrm{mol} / \mathrm{L} \mathrm{As}_{2} \mathrm{O}_{3}$ and $\mathrm{As}_{2} \mathrm{O}_{3}$ nanoparticles for 24 h. $1 \times 10^{6} \mathrm{NB} 4$ cells were stained with Rhodamine 123 (Sigma). Cells were washed with PBS, suspended with new fresh medium. Mean Fluorescence Intensity (MFI) was on behalf of Mitochondrial Membrane Potential (MMP) and examined the MFI in each group with Flow cytometric.

\section{Western blotting analysis}

The expression level of p-PTEN, p-AKT, Bax, caspase-3, caspase- 9 and AIF was determined by Western Blotting analysis in 3 groups (control, $\mathrm{As}_{2} \mathrm{O}_{3}, \mathrm{As}_{2} \mathrm{O}_{3}$ nanoparticles). The extracted total protein was loaded on SDS-polyacrylamide gel. The protein was separated after electrophoresis and transferred to a nitrocellulose membrane. Membrane was blocked with 5\% non-fat dry milk at room temperature for $2 \mathrm{~h}$ and incubated with primary antibody: p-PTEN, p-AKT, caspase-3 rabbit mAb, caspase-9 mouse mAb (Cell Signaling Technology, Danvers, MA), Bax rabbit mAb (Proteintech Group, Chicago, America), AIF rabbit $\mathrm{mAb}$ and $\beta$-actin mouse $\mathrm{mAb}$ (Beyotime, Shanghai, China). The membrane was washed with PBST thrice for 10 min each time and then incubated with horseradish peroxidase (HRP)-labeled goatanti-rabbit or goat-anti-mouse secondary antibody (Beyotime, Shanghai, China) at room temperature for $1 \mathrm{~h}$. Membranes were washed for 3 times with PBST. Exposure to $\operatorname{Kodak}^{\circledR}$ Xomat LS film (Eastman Kodak Company, New Haven, CT) after incubating with enhanced chemiluminescence (ECL) substrate (Bio-Rad, Hercules, CA, USA). Densitometry was applied with Kodak $^{\circledR}$ 1D image analysis software (Eastman Kodak Company).

\section{Results}

\section{Inhibitory effect of $\mathrm{As}_{2} \mathrm{O}_{3}$ nanoparticles on $\mathrm{NB} 4$ cell proliferation}

The inhibitory effect of $\mathrm{As}_{2} \mathrm{O}_{3}$ nanoparticles and $\mathrm{As}_{2} \mathrm{O}_{3}$ on NB4 cell proliferation was examined by MTT assay. As shown in Figure 1, the drugs had time and dose dependent antiproliferative effects on NB4 cells. Furthermore, the inhibitory effect of $\mathrm{As}_{2} \mathrm{O}_{3}$ nanoparticles was much higher than traditional $\mathrm{As}_{2} \mathrm{O}_{3}$. 

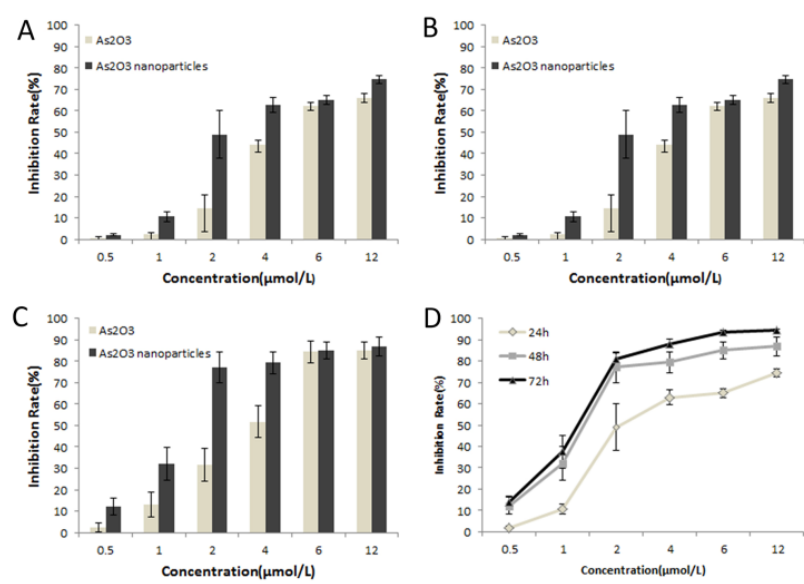

Figure 1. Effect of $\mathrm{As}_{2} \mathrm{O}_{3}$ nanoparticles and $\mathrm{As}_{2} \mathrm{O}_{3}$ on $\mathrm{NB} 4$ cells proliferation. NB4 cells were incubated with drugs for: (A) $24 \mathrm{~h}$; (B) $48 \mathrm{~h}$; (C) $72 \mathrm{~h}$; (D) Inhibitory effect of $\mathrm{As}_{2} \mathrm{O}_{3}$ nanoparticles on $\mathrm{NB} 4$ cell proliferation at $24 \mathrm{~h}, 48 \mathrm{~h}$ and $72 \mathrm{~h}$.

\section{Results of Hoechst 33342/PI staining}

NB4 cells were incubated with $3 \mu \mathrm{mol} / \mathrm{L} \mathrm{As}_{2} \mathrm{O}_{3}$ nanoparticles or $\mathrm{As}_{2} \mathrm{O}_{3}$ for $24 \mathrm{~h}$. Hoechst 33342/PI double staining was performed to observe the cell nuclear apoptosis or necrosis situation. Apoptotic cells were stained blue by Hoechst 33342 with pyknosis and stained red by PI with chromatin condensation. As shown in Figure 2, apoptosis was present after being treated with $\mathrm{As}_{2} \mathrm{O}_{3}$ nanoparticles or $\mathrm{As}_{2} \mathrm{O}_{3}$.

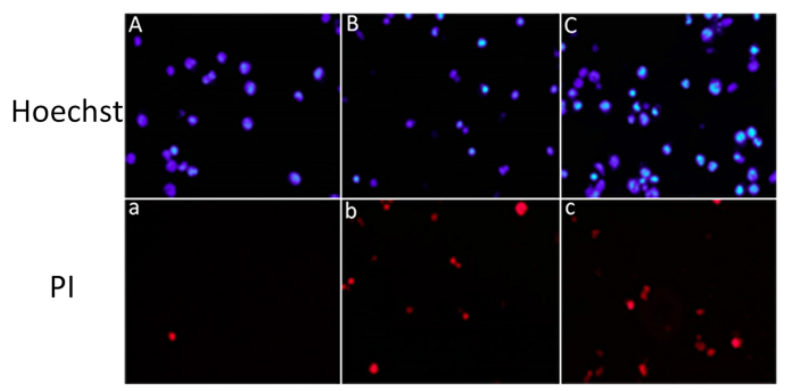

Figure 2. Morphology of NB4 cells being stained by Hoechst 33342/PI under fluorescence microscopy. A (a) Control; B (b) 3 $\mu \mathrm{mol} / \mathrm{L} \mathrm{As}_{2} \mathrm{O}_{3} ; \mathrm{C}$ (c) $\mathrm{As}_{2} \mathrm{O}_{3}$ nanoparticles (bar $=50 \mu \mathrm{m}$ ).

\section{$\mathrm{As}_{2} \mathrm{O}_{3}$ nanoparticles induce $\mathrm{NB} 4$ cell apoptosis}

Both $\mathrm{As}_{2} \mathrm{O}_{3}$ nanoparticles and $\mathrm{As}_{2} \mathrm{O}_{3}$ can induce NB4 cells apoptosis. Figure 3 showed a dose-dependent inducing apoptosis effect of $\mathrm{As}_{2} \mathrm{O}_{3}$ nanoparticles and $\mathrm{As}_{2} \mathrm{O}_{3}$ on NB4 cells. Furthermore, $\mathrm{As}_{2} \mathrm{O}_{3}$ nanoparticles had higher inhibition ability than $\mathrm{As}_{2} \mathrm{O}_{3}$.

\section{Mitochondrial membrane potential}

The mean fluorescence intensity level of control group is 1313.67 MFI. Meanwhile, the mean fluorescence intensity level of $1.5 \mu \mathrm{mol} / \mathrm{L}$ and $3.0 \mu \mathrm{mol} / \mathrm{L} \mathrm{As}_{2} \mathrm{O}_{3}$ is $1085.09 \mathrm{MFI}$ and $881.20 \mathrm{MFI}$. What's more, the mean fluorescence intensity level of $1.5 \mu \mathrm{mol} / \mathrm{L}$ and $3.0 \mu \mathrm{mol} / \mathrm{L} \mathrm{As}_{2} \mathrm{O}_{3}$ nanoparticles is
911.05 MFI and 371.17 MFI. $\mathrm{As}_{2} \mathrm{O}_{3}$ nanoparticles can significantly decrease the mean fluorescence intensity level of NB4 cells than $\mathrm{As}_{2} \mathrm{O}_{3}$ (Figure 4).
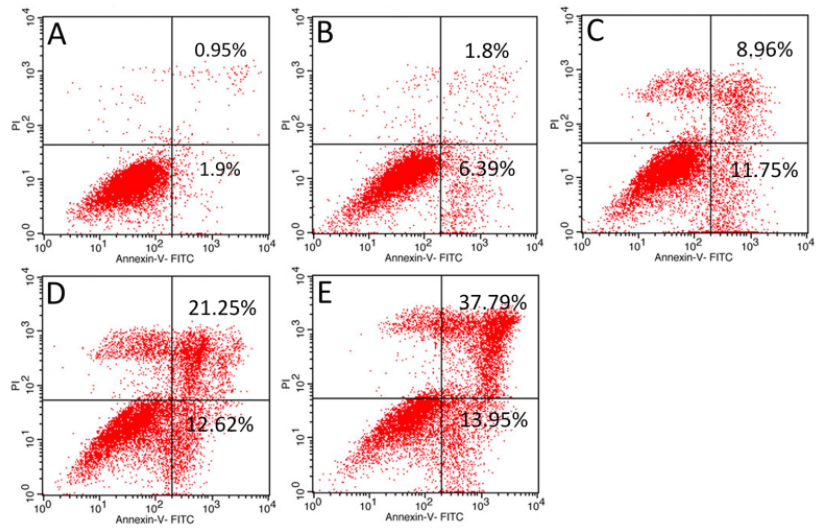

Figure 3. Apoptosis of $\mathrm{NB} 4$ cells after being treated with $\mathrm{As}_{2} \mathrm{O}_{3}$ nanoparticles or $\mathrm{As}_{2} \mathrm{O}_{3}$. NB4 cells were treated as follows with an apoptosis rate: (A) Control, 0.95\%; (B) $1.5 \mu \mathrm{mol} / \mathrm{L} \mathrm{As}_{2} \mathrm{O}_{3}, 1.8 \%$; (C) $1.5 \mu \mathrm{mol} / \mathrm{L} \mathrm{As}_{2} \mathrm{O}_{3}$ nanoparticles, 8.96\%; (D) $3.0 \mu \mathrm{mol} / \mathrm{L} \mathrm{As}_{2} \mathrm{O}_{3}$, 21.25\%; (E) $3.0 \mu \mathrm{mol} / \mathrm{L} \mathrm{As}_{2} \mathrm{O}_{3}$ nanoparticles, $37.79 \%$.
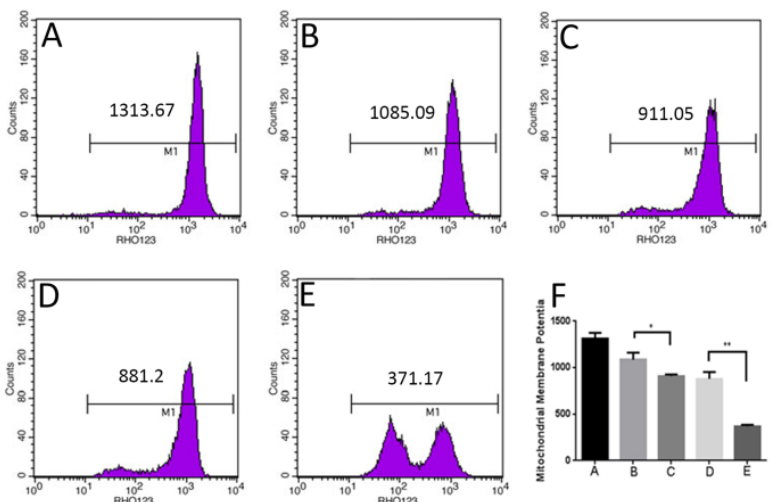

Figure 4. Mitochondrial membrane potential of NB4 cells was examined by flow cytometry after being stained by Rhodamine123. (A) Control group; (B) $1.5 \mu \mathrm{mol} / \mathrm{L} \mathrm{As}_{2} \mathrm{O}_{3}$; (C) $1.5 \mu \mathrm{mol} / \mathrm{L} \mathrm{As}_{2} \mathrm{O}_{3}$ nanoparticles; (D) $3 \mu \mathrm{mol} / \mathrm{L} \quad \mathrm{As}_{2} \mathrm{O}_{3} ; \quad$ (E) $3 \mu \mathrm{mol} / \mathrm{L} \quad \mathrm{As}_{2} \mathrm{O}_{3}$ nanoparticles; (F) The quantitative mitochondrial membrane potential levels of all groups; ${ }^{*} P<0.05{ }^{* *} P<0.01$.

\section{Protein levels of PTEN, Akt and Bax of NB4 cells treated with $\mathrm{As}_{2} \mathrm{O}_{3}$ nanoparticles}

Protein levels of PTEN, Akt and Bax of NB4 cells incubated with $\mathrm{As}_{2} \mathrm{O}_{3}$ and $\mathrm{As}_{2} \mathrm{O}_{3}$ nanoparticles were detected by Western blotting. Both $\mathrm{As}_{2} \mathrm{O}_{3}$ and $\mathrm{As}_{2} \mathrm{O}_{3}$ nanoparticles can decrease the protein expression level of PTEN and p-Akt at the concentration of $1.5 \mu \mathrm{mol} / \mathrm{L}$ and $3.0 \mu \mathrm{mol} / \mathrm{L}$, and the drugs increase the expression of p-PTEN and Bax.

Meanwhile, the expression of PTEN and p-Akt were much lower in the $\mathrm{As}_{2} \mathrm{O}_{3}$ nanoparticles group than in the $\mathrm{As}_{2} \mathrm{O}_{3}$ group, as well as the levels of p-PTEN and Bax were much higher in the former group than the latter with a dosedependent manner (Figure 5). 


\section{Protein levels of caspase-3, caspase-9 and AIF of NB4 cells treated with $\mathrm{As}_{2} \mathrm{O}_{3}$ nanoparticles}

At the concentration of $1.5 \mu \mathrm{mol} / \mathrm{L}$, the protein levels of caspase-3 and caspase-9 were much higher in $\mathrm{As}_{2} \mathrm{O}_{3}$ nanoparticles group than $\mathrm{As}_{2} \mathrm{O}_{3}$ group. While, the levels were lower in $3.0 \mu \mathrm{mol} / \mathrm{L} \mathrm{As}_{2} \mathrm{O}_{3}$ nanoparticles group than 3.0 $\mu \mathrm{mol} / \mathrm{L} \mathrm{As}_{2} \mathrm{O}_{3}$ group (Figure 5).

We further examined the level of AIF of NB4 cells. Figure 5 showed that the AIF level was higher in the $\mathrm{As}_{2} \mathrm{O}_{3}$ nanoparticles group than the group of $\mathrm{As}_{2} \mathrm{O}_{3}$ solution.

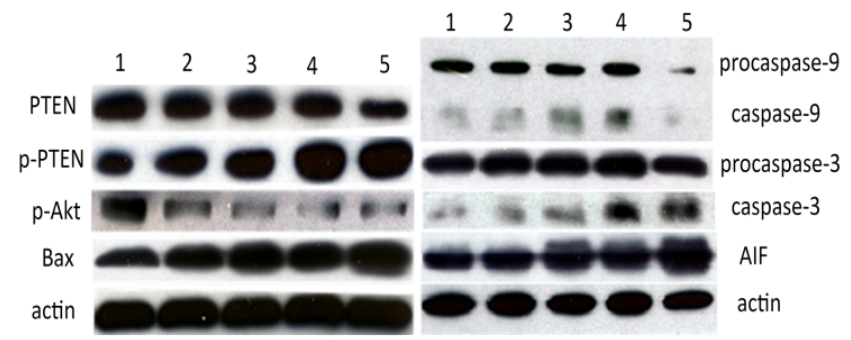

Figure 5. Protein levels of PTEN, p-PTEN, p-Akt, Bax, caspase-3, caspase-9 and AIF of NB4 cells following treatment of $\mathrm{As}_{2} \mathrm{O}_{3}$ nanoparticles or $\mathrm{As}_{2} \mathrm{O}_{3}$ for $24 \mathrm{~h}$. NB4 cells were treated as follows: (1) Control; (2) $1.5 \mu \mathrm{mol} / \mathrm{L} \quad \mathrm{As}_{2} \mathrm{O}_{3}$; (3) $1.5 \mu \mathrm{mol} / \mathrm{L} \quad \mathrm{As}_{2} \mathrm{O}_{3}$ nanoparticles nanoparticles;(4) $3 \mu \mathrm{mol} / \mathrm{L} \mathrm{As} \mathrm{O}_{3}$; (5) $3 \mu \mathrm{mol} / \mathrm{L} \mathrm{As}_{2} \mathrm{O}_{3}$ nanoparticles.

\section{Discussion}

$\mathrm{As}_{2} \mathrm{O}_{3}$, a kind of traditional Chinese medicine, had been approved as frontline treatment for APL by FDA for many years. It could also be used in other solid cancer, such as liver cancer, prostate cancer, cervical cancer and breast cancer [9,12-18]. However, its clinical application is somehow limited owing to its high toxicity to the normal tissues. Therefore, different formulations of $\mathrm{As}_{2} \mathrm{O}_{3}$ with higher antitumor efficacy and lower toxicity are needed to be further studied.

Several kinds of $\mathrm{As}_{2} \mathrm{O}_{3}$ nanoparticles have been reported. Qian developed a scFvCD44v6-decorated PEG-PDLLA nanoparticle, which scFv-As-NP could target delivery of As to CD44v6-positive tumor cells PANC-1 [19]. The $\mathrm{As}_{2} \mathrm{O}_{3}$ nanoparticles with better antitumor efficacy can highly improve the drug concentration in tumor site but not normal tissues owing to the EPR effect and its better targeting effect. Nanobin encapsulation of $\mathrm{As}_{2} \mathrm{O}_{3}$ improves the pharmacokinetics and antitumor efficacy of $\mathrm{As}_{2} \mathrm{O}_{3}$ in a murine model of breast cancer and lymphoma [20,21].

In our previous study, we prepared small-sized $(<10 \mathrm{~nm}$ and $\sim 40 \mathrm{~nm}) \mathrm{As}_{2} \mathrm{O}_{3}$ nanoparticles with sol-gel method [11]. Herein, the superiority efficacy of proliferationinhibition and apoptosisinduction effects in vitro of $\mathrm{As}_{2} \mathrm{O}_{3}$ nanoparticles than $\mathrm{As}_{2} \mathrm{O}_{3}$ were further confirmed by evaluating MTT assay, apoptosis detection with flow cytometric assay, mitochondrial membrane potential, p-PTEN, p-AKT, Bax, caspase-3, caspase-9 and AIF protein levels. A much smaller dose of $\mathrm{As}_{2} \mathrm{O}_{3}$ nanoparticles can achieve a good antitumor effect, which would reduce the systemic toxic side effects with a reduction of toxicity.

$\mathrm{As}_{2} \mathrm{O}_{3}$ has a property of proliferation inhibition of APL cell, such as NB4 cell lines. $\mathrm{As}_{2} \mathrm{O}_{3}$ nanoparticles, even at a low concentration of $2 \mu \mathrm{mol} / \mathrm{L}$ (Figure 1), can significantly inhibit the growth of NB4 cells. $\mathrm{As}_{2} \mathrm{O}_{3}$ nanoparticles can also induce apoptosis of NB4 cells in a dose-dependent manner (Figure 3). PTEN/Akt signalling pathway is involved in antitumor process [22,23]. PTEN is closely associated with PI3K/Akt pathway. It is a negative regulator of PI3K/Akt pathway owing to its IP3 phosphatase activity, which influences the cell proliferation and apoptosis [24,25]. And PI3K/Akt pathway has been proposed to inhibit Bax translocation from cytoplasm to mitochondria [26]. The inactivation of Akt can induce Bax translocate to mitochondria, which can decrease the mitochondrial membrane potential to induce apoptosis. In our present study, both $\mathrm{As}_{2} \mathrm{O}_{3}$ nanoparticles and $\mathrm{As}_{2} \mathrm{O}_{3}$ can increase the protein level of p-PTEN and decrease the level of p-Akt (Figure 5). Here we demonstrated that the induceapoptosis of $\mathrm{As}_{2} \mathrm{O}_{3}$ nanoparticles and $\mathrm{As}_{2} \mathrm{O}_{3}$ is connected with PTEN and Akt. $\mathrm{As}_{2} \mathrm{O}_{3}$ and $1.5 \mu \mathrm{mol} / \mathrm{L} \mathrm{As}_{2} \mathrm{O}_{3}$ nanoparticles could increase caspase- 3 and caspase- 9 protein expression. However, the $3 \mu \mathrm{mol} / \mathrm{L} \mathrm{As}_{2} \mathrm{O}_{3}$ nanoparticles could improve the protein expression of AIF but not caspase-3 and caspase-9. We demonstrate that the apoptosis of $\mathrm{As}_{2} \mathrm{O}_{3}$ and $\mathrm{As}_{2} \mathrm{O}_{3}$ nanoparticles in a lower concentration is related with a caspase-dependent mitochondrial apoptosis pathway, but higher concentration of $\mathrm{As}_{2} \mathrm{O}_{3}$ nanoparticles induce NB4 cells apoptosis by a caspase-independent mitochondrial apoptosis pathway.

\section{Conclusions}

In conclusion, $\mathrm{As}_{2} \mathrm{O}_{3}$ nanoparticles can inhibit proliferation and induce apoptosis of APL cells, and the induce-apoptosis effect was correlated with PTEN/Akt signaling pathway. $\mathrm{As}_{2} \mathrm{O}_{3}$ nanoparticles are selective and potential anti-APL agents which could inhibit proliferation and induce apoptosis of APL cells with high efficacy.

\section{Acknowledgement}

This work was supported by the Department of Science and Technology of Jilin Province, China (Grant Number 20150204005YY).

\section{Conflicts of Interest}

The authors have no conflicts of interest to declare.

\section{Ethical Statement}

This article does not contain any studies with human participants or animals performed by any of the authors.

\section{References}

1. Licht JD. Acute promyelocytic leukemia-weapons of mass differentiation. N Engl J Med 2009; 360: 928-930. 
2. Wang ZY, Chen Z. Acute promyelocytic leukemia: from highly fatal to highly curable. Blood 2008; 111: 2505-2515.

3. Antman KH. Introduction: the history of arsenic trioxide in cancer therapy. Oncologist 2001; 6: 1-2.

4. Bairey O, Vanichkin A, Shpilberg O. Arsenic-trioxideinduced apoptosis of chronic lymphocytic leukemia cells. Int J Lab Hematol 2010; 32: 77-85.

5. Anam A, Scarlet Xiaoyan W, Lucy G. Recent advances in arsenic trioxide encapsulated nanoparticles as drug delivery agents to solid cancers. J Biomed Res 2017.

6. Tian C, Gao P, Zheng Y. Redox status of thioredoxin-1 (TRX1) determines the sensitivity of human liver carcinoma cells (HepG2) to arsenic trioxide-induced cell death. Cell Res 2008; 18: 458-471.

7. Diepart C, Karroum O, Magat J. Arsenic trioxide treatment decreases the oxygen consumption rate of tumor cells and radiosensitizes solid tumors. Cancer Res 2012; 72: 482-490.

8. Wang X, Yang L, Chen ZG. Application of nanotechnology in cancer therapy and imaging. CA Cancer J Clin 2008; 58: 97-110.

9. Jadhav V, Ray P, Sachdeva G. Biocompatible arsenic trioxide nanoparticles induce cell cycle arrest by p21(WAF1/CIP1) expression via epigenetic remodeling in LNCaP and PC3 cell lines. Life Sci 2016; 148: 41-52.

10. Davis ME, Chen ZG, Shin DM. Nanoparticle therapeutics: an emerging treatment modality for cancer. Nat Rev Drug Discov 2008; 7: 771-782.

11. Dong X, Ma N, Liu M. Effects of As2O3 nanoparticles on cell growth and apoptosis of NB4 cells. Exp Ther Med 2015; 10: 1271-1276.

12. Zhang KZ, Zhang QB, Zhang QB. Arsenic trioxide induces differentiation of CD133+ hepatocellular carcinoma cells and prolongs posthepatectomy survival by targeting GLI1 expression in a mouse model. J Hematol Oncol 2014; 7: 28.

13. Ma Y, Wang J, Liu L. Genistein potentiates the effect of arsenic trioxide against human hepatocellular carcinoma: role of Akt and nuclear factor-kappaB. Cancer Lett 2011; 301: 75-84.

14. Chen FY, Yi JW, Gu ZJ. Inorganic phosphate-triggered release of anti-cancer arsenic trioxide from a self-delivery system: an in vitro and in vivo study. Nanoscale 2016; 8: 6094-6100.

15. Kang YH, Yi MJ, Kim MJ. Caspase-independent cell death by arsenic trioxide in human cervical cancer cells: reactive oxygen species-mediated poly (ADP-ribose) polymerase-1 activation signals apoptosis-inducing factor release from mitochondria. Cancer Res 2004; 64: 8960-8967.

16. Sun RC, Board PG, Blackburn AC. Targeting metabolism with arsenic trioxide and dichloroacetate in breast cancer cells. Mol Cancer 2011; 10: 142.
17. Thomas-Schoemann A, Batteux F, Alexandre J. A new strategy to target regulatory $\mathrm{T}$ cells in solid tumors. Oncoimmunology 2013; 2: e23338.

18. Si L, Jiang F, Li Y. Induction of the mesenchymal to epithelial transition by demethylation- activated microRNA-200c is involved in the anti-migration/invasion effects of arsenic trioxide on human breast cancer cells. Mol Carcinog 2015; 54: 859-869.

19. Qian C, Wang Y, Chen Y. Suppression of pancreatic tumor growth by targeted arsenic delivery with anti-CD44v6 single chain antibody conjugated nanoparticles. Biomaterials 2013; 34: 6175-6184.

20. Ahn RW, Chen F, Chen H. A novel nanoparticulate formulation of arsenic trioxide with enhanced therapeutic efficacy in a murine model of breast cancer. Clin Cancer Res 2010; 16: 3607-3617.

21. Ahn RW, Barrett SL, Raja MR. Nano-encapsulation of arsenic trioxide enhances efficacy against murine lymphoma model while minimizing its impact on ovarian reserve in vitro and in vivo. PLoS One 2013; 8: e58491.

22. Zhang X, Jia S, Yang S. Arsenic trioxide induces G2/M arrest in hepatocellular carcinoma cells by increasing the tumor suppressor PTEN expression. J Cell Biochem 2012; 113: 3528-3535.

23. McCubrey JA, Steelman LS, Abrams SL. Roles of the RAF/MEK/ERK and PI3K/PTEN/AKT pathways in malignant transformation and drug resistance. Adv Enzyme Regul 2006; 46: 249-279.

24. Dahia PL, Aguiar RC, Alberta J. PTEN is inversely correlated with the cell survival factor $\mathrm{Akt} / \mathrm{PKB}$ and is inactivated via multiple mechanisms in haematological malignancies. Hum Mol Genet 1999; 8: 185-193.

25. Chow LM, Baker SJ. PTEN function in normal and neoplastic growth. Cancer Lett 2006; 241: 184-196.

26. Tsuruta F, Masuyama N, Gotoh Y. The phosphatidylinositol 3-kinase (PI3K)-Akt pathway suppresses Bax translocation to mitochondria. J Biol Chem 2002; 277: 14040-14047.

\section{*Correspondence to}

Ziling Liu

Cancer Center

The First Hospital of Jilin University

Jilin

P.R. China 